\title{
Properties of Extract from Okara by Its Subcritical Water Treatment
}

AUTHOR(S):

Wiboonsirikul, Jintana; Mori, Masayuki; Khuwijitjaru, Pramote; Adachi, Shuji

\section{CITATION:}

Wiboonsirikul, Jintana ... [et al]. Properties of Extract from Okara by Its Subcritical Water Treatment. International Journal of Food Properties 2013, 16(5): 974-982

\section{ISSUE DATE:}

2013-07-04

URL:

http://hdl.handle.net/2433/189737

\section{RIGHT:}

This is an Accepted Manuscript of an article published in "International Journal of Food Properties" on 02/04/2013, available online: http://www.tandfonline.com/10.1080/10942912.2011.573119.; この論文は出版社版でありません。引 用の際には出版社版をご確認ご利用ください。; This is not the published version. Please cite only the published version. 


\title{
PROPERTIES OF EXTRACT FROM OKARA BY ITS SUBCRITICAL WATER TREATMENT
}

\author{
Jintana Wiboonsirikul, ${ }^{1}$ Masayuki Mori, ${ }^{2}$ Pramote Khuwijitjaru, ${ }^{3}$ and Shuji Adachi ${ }^{2}$ \\ ${ }^{1}$ Department of Food Science and Technology, Faculty of Agricultural Technology, Phetchaburi Rajabhat \\ University, 38 Moo 8, Hard Chao Samran Road, Na Wung, Muang, Phetchaburi 76000, Thailand \\ ${ }^{2}$ Division of Food Science and Biotechnology, Graduate School of Agriculture, Kyoto University, Sakyo-ku, \\ Kyoto 606-8502, Japan \\ ${ }^{3}$ Department of Food Technology, Faculty of Engineering and Industrial Technology, Silpakorn University, \\ Nakhon Pathom 73000, Thailand
}

\begin{abstract}
Okara was treated with subcritical water at temperatures ranging from 170 to $260{ }^{\circ} \mathrm{C}$ for various times. After clarification, the extracts were analyzed for their protein and carbohydrate contents, DPPH radical scavenging activity and antioxidative activity. The carbohydrate content significantly decreased with the increasing treatment temperature and time. The protein content, however, increased with the increasing treatment temperature and slightly decreased with a heating time longer than $10 \mathrm{~min}$. The extract obtained from the subcritical water treatment at $240^{\circ} \mathrm{C}$ for $5 \mathrm{~min}$, which would be used to evaluate the antioxidative activity, provided the relatively highest radical scavenging activity and the activity decreased with the prolonging heating time and temperature. The extract also exhibited a suppressive activity to the autoxidation of linoleic acid with the increasing weight ratio of the extract to linoleic acid. The results clearly showed okara still contained highly valuable substances for human consumption.
\end{abstract}

Keywords: okara, subcritical water, antioxidant, radical scavenging activity, protein, carbohydrate.

\section{INTRODUCTION}

Okara is a by-product from the soymilk and tofu industries. Raw okara, also called soy pulp, is obtained from ground soybeans after extraction of the water extractable fraction to produce the soymilk and tofu. Large quantities of okara from the industries are generally used for animal feed or discarded. However, it has still been rich in protein $(24.5-37.5 \mathrm{~g} / 100 \mathrm{~g}$ dry material), lipids (9.3-22.3 g/100 g dry material), and dietary fiber (14.5-55.4 $\mathrm{g} / 100 \mathrm{~g}$ dry material). In addition, it also contains phenolic substances and isoflavone $\left(0.14 \mathrm{~g} / 100 \mathrm{~g}\right.$ dry material) ${ }^{[1-3]}$ These substances in the okara have shown radical scavenging and antioxidative activities. The peptide and protein obtained from okara have an antioxidative activity and angiotensin-converting enzyme inhibition. ${ }^{[4,5]}$ The okara is also an important source of dietary fiber and polysaccharides. The main monomers in the okara fiber are glucose, galactose, uronic acids, arabinose and xylose ${ }^{[6]}$ The phenolic substances and isoflavones are active compounds in the okara, which have shown an antioxidant capacity. ${ }^{[7]}$ These valuable substances have normally been recovered by traditional methods using organic solvents, which are toxic and questionable for human health if used for food processing.

Subcritical water is hot water between 100 and $374^{\circ} \mathrm{C}$ under high pressure in order to maintain its liquid state (critical point of water, $22.4 \mathrm{MPa}$ and $374^{\circ} \mathrm{C}$ ). It is considered as an environmentally friendly and economic solvent in comparison to organic solvents such as methanol, acetone and hexane. The advantages of subcritical water depend on its temperature because of its decreasing relative dielectric constant of water from around 80 at $25^{\circ} \mathrm{C}$ to almost 27 at $250^{\circ} \mathrm{C}$, which is close to that of methanol and ethanol. ${ }^{[8]}$ Thus the subcritical water has the ability to dissolve hydrophobic substances from agricultural by-products. In addition, because the concentrations of the ion products or hydrogen and hydroxyl ions in the subcritical water are three orders of magnitude greater than that in ambient water, the water acts as an acid or base catalyst in chemical reactions. As the okara contains both protein and saccharides, it would be subjected to non-enzymatic browning including Maillard and caramelization reactions at high 
temperature. Products from the reactions also have a radical scavenging activity. ${ }^{[9,10]}$ In this study, extracts obtained from the treatment of the okara with subcritical water at various temperatures and times were evaluated for their protein and carbohydrate contents, DPPH radical scavenging activity and antioxidative one.

\section{MATERIALS AND METHODS}

\section{Materials}

Dried okara and water-soluble soy polysaccharides (SSPS) were obtained from Fuji Oil. (Osaka, Japan). Linoleic acid (purity $>\quad 90 \%$ ) and 1,1-diphenyl-2-picrylhydazyl (DPPH) were purchased from Wako Pure Chemical Industries (Osaka, Japan).

\section{Preparation of okara extract by subcritical water treatment}

Subcritical water treatment of the okara was done using a batch-type vessel with a net volume of $9 \mathrm{~mL}$ (Taiatsu Techno Corporation, Osaka, Japan). The vessel was placed in a gas chromatograph oven (GC-17A, Shimadzu, Kyoto, Japan) to control the temperature. The okara sample $(140 \mathrm{mg})$ and water $(7$ $\mathrm{mL}$ ) were added to the vessel. After sealing, the vessel was heated to the desired temperatures from 170 to $260^{\circ} \mathrm{C}$ and held for specific times from 2 to $120 \mathrm{~min}$. The heat-up times before reaching each specific temperature were less than $10 \mathrm{~min}$. The pressure at each temperature was not measured but estimated based on the IAPWS formulation. ${ }^{[8]}$ The vessel was immediately cooled to room temperature in the ice-water bath. The okara extract was clarified through filter paper (No. 2, Advantec, Tokyo, Japan) and the obtained filtrate was then lyophilized for further analyses.

\section{Determination of carbohydrate and protein contents}

The total carbohydrate content was determined using the Phenol-sulfuric method. ${ }^{[11]}$ Briefly, a diluted sample $(0.2 \mathrm{~mL})$ was mixed with $5 \%$ phenol reagent $(0.2 \mathrm{~mL})$, and then sulfuric acid $(1 \mathrm{~mL})$ was added. After $10 \mathrm{~min}$, the mixture was thoroughly mixed and allowed to cool for another $10 \mathrm{~min}$. The total carbohydrate content was evaluated using a UV-1200 spectrophotometer (Shimadzu) at $490 \mathrm{~nm}$ with water as the blank. Glucose was used as the standard. The protein content of the okara extract was determined according to the Lowry-Folin assay. ${ }^{[12]}$ Bovine serum albumin (BSA) was used as the protein standard.

\section{Determination of antioxidative activity}

Inhibition of bulk linoleic acid oxidation: The product from the treatment at $240^{\circ} \mathrm{C}$ for $5 \mathrm{~min}$ was tested for its ability to inhibit the oxidation of linoleic acid. A solution of linoleic acid in methanol (10 $\mathrm{mg} / \mathrm{mL}$ ) was prepared then transferred to several 0.3 $\mathrm{mL}$ vials. The methanol solution of the subcritical water-treated sample was prepared and added to the cup to make the final sample:linoleic acid mass ratios of 0.0016 to 16 . The volume was adjusted to $5 \mathrm{~mL}$ with methanol, then $0.3 \mathrm{~mL}$ of the mixture was transferred to an open glass cup. Methanol was evaporated under vacuum. The sample glass cups were placed in a desiccator, which maintained the relative humidity at $0 \%$ using phosphorus pentoxide, and stored in an oven at $65^{\circ} \mathrm{C}$. Samples at the beginning $(0$ h) and at $12 \mathrm{~h}$ were removed and analyzed for the amount of unoxidized linoleic acid using the GC-FID method. ${ }^{[13]}$

DPPH radical scavenging activity: A Sample was diluted with methanol at various concentrations. The diluted sample $(4 \mathrm{~mL})$ was mixed with $0.5 \mathrm{mmol} / \mathrm{L}$ DPPH in methanol $(1 \mathrm{~mL})$. The mixture was well shaken and placed in the dark for $20 \mathrm{~min}$ at ambient temperature. The remaining radical content was evaluated using the UV-1200 spectrophotometer at the absorbance of $516 \mathrm{~nm}$. The radical scavenging activity was calculated as follows:

Radical scavenging activity $=\frac{(A-B+C)}{A} \times 100 \%$

where $A, B$ and $C$ are the absorbance of DPPH solution without a sample, the absorbance of the DPPH solution containing the sample and the absorbance of the blank containing methanol solution of sample without DPPH, respectively. The radical scavenging activity of the okara extracts was evaluated by comparison with ascorbic acid and the low molecular weight portion of the water-soluble soy polysaccharides (SSPS). The low molecular weight portion of SSPS was prepared according to the method of Fang et al. ${ }^{[13]}$ Briefly, the aqueous solution of SSPS (5\%) and an equal volume of ethanol were vortex-mixed and centrifuged at 3000 rpm for 15 min (LX120, Tomy, Tokyo, Japan). The upper liquid was collected and then water and the residue were added to the beginning volume and centrifuged again. The upper liquid was collected and 
mixed with the first portion. The mixture was then evaporated and lyophilized to obtain the powdered low molecular weight portion of SSPS.

\section{Statistical Analysis}

Each analysis was conducted in triplicate. The experimental data of the okara extract were evaluated for an analysis of the variance (ANOVA) and mean comparisons with Duncan's multiple range test at the significant level of $\mathrm{P}<0.05$ using the IBM SPSS statistics software (IBM Corperation, NY, USA.).

\section{RESULTS AND DISCUSSION}

Effects of treatment temperature and time on carbohydrate and protein contents, and DPPH radical scavenging activity

Figures $1 \mathrm{~A}$ and $1 \mathrm{~B}$ show the dependencies of the carbohydrate and protein contents of the okara extract on the treatment temperature from 170 to $260^{\circ} \mathrm{C}$ and treatment time from 2 to $120 \mathrm{~min}$. The protein content significantly increased with the increasing treatment temperature from 170 to $260^{\circ} \mathrm{C}$ for the same treatment time. In contrast, the carbohydrate content was lower at the higher treatment temperature $(\mathrm{P}<0.05)$. At the treatment temperatures of 170 and $200^{\circ} \mathrm{C}$, the protein content increased with longer treatment time. However, prolonging the treatment time caused decreasing in the carbohydrate content at all treatment temperatures. A heating longer than $5 \mathrm{~min}$ at all the treatment temperatures decreased the carbohydrate content, and a sharp decrease in the content was observed at $200^{\circ} \mathrm{C}$. However, the protein content did not clearly change when the okara was treated for longer than $5 \mathrm{~min}$. While the highest content of the carbohydrate was obtained when the okara was treated for $5 \mathrm{~min}$ at $170^{\circ} \mathrm{C}$, the highest protein content was instead found at 240 and $260^{\circ} \mathrm{C}$.

Solubility of the protein in the okara is normally low due to its strong aggregation through a hydrophobic interaction and nonhomogeneously bound to the other components such as the non-cellulosic polysaccharide and cellulose. ${ }^{[14,15]}$ The increase in the protein solubility during the subcritical water treatment at higher temperatures for short treatment time may result from the hydrolysis of the peptide bonds and increase in the degree of deamidation at the high treatment temperature. ${ }^{[16]}$ The decrease in the carbohydrate content at the higher treatment temperature would be due to the hydrolysis of the poly- or oligosaccharide

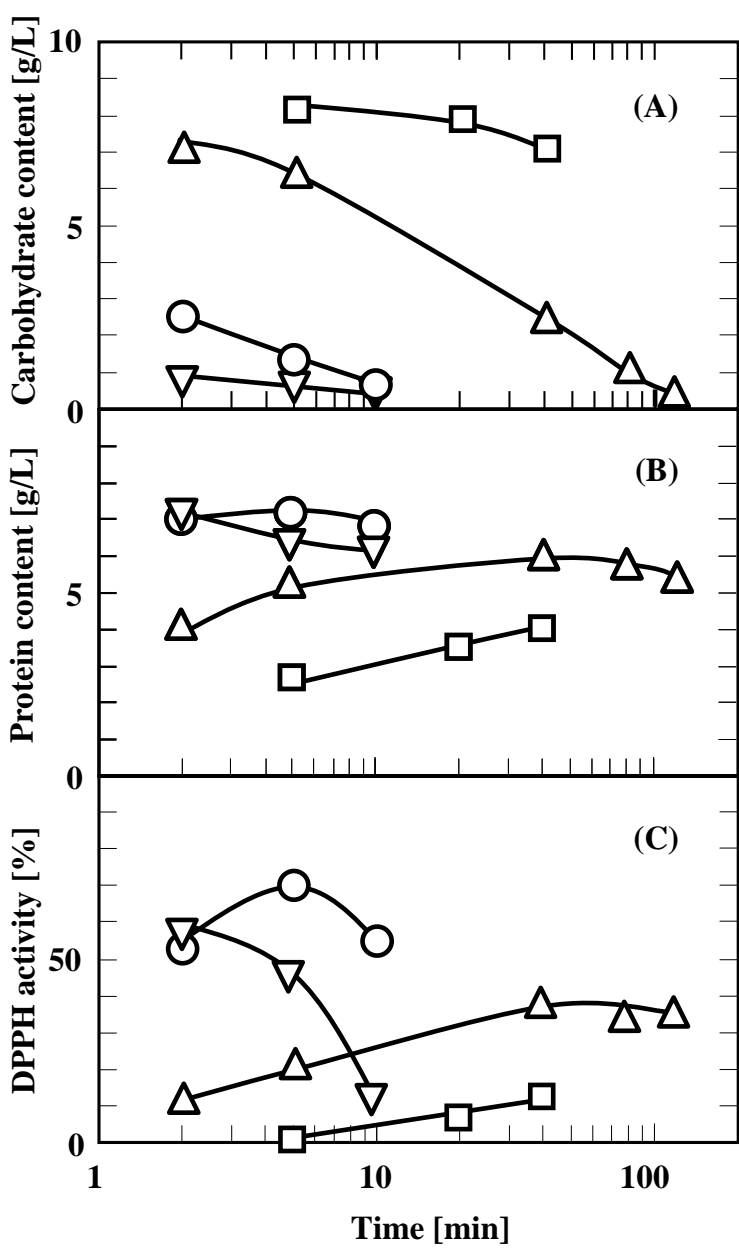

Figure 1 Carbohydrate and protein contents and DPPH radical scavenging activity of the extracts from okara treated with subcritical water at $170^{\circ} \mathrm{C}(\square), 200^{\circ} \mathrm{C}(\triangle)$, $240^{\circ} \mathrm{C}(\bigcirc)$, and $260^{\circ} \mathrm{C}(\nabla)$ for various times.

and degradation of the resulting monosaccharides due to the high ion products of water at the high temperatures

Figure 1C shows the changes in the DPPH radical scavenging activity of the extracts at various treatment temperatures and times. The relatively highest activity was obtained when the okara was treated at $240^{\circ} \mathrm{C}$ for $5 \mathrm{~min}$, but there was almost no activity when treated at $170^{\circ} \mathrm{C}$ for the same treatment time. The activity of the extracts was higher with prolonged heating of the extracts obtained at $200^{\circ} \mathrm{C}$, but became lower for the treatment times longer than $5 \mathrm{~min}$ in the ones obtained at 240 and $260^{\circ} \mathrm{C}$. The radical scavenging activity may result from several substances including cell wall polysaccharides, such as pectin and hemicelluloses, protein and peptide, phenolic substances and isoflavones. ${ }^{[17,18]}$ At the treatment temperatures higher than $200^{\circ} \mathrm{C}$ for a short treatment time within $5 \mathrm{~min}$, the activity may not come from only the polysaccharides because of their low content, but might come from the 
protein and phenolic substances. Although the carbohydrates and proteins were present in the extract from the okara treated at $170^{\circ} \mathrm{C}$, the radical scavenging activity is still low. These facts would indicate that the active substances for the radical scavenging activity may be the products from the carbohydrate degradation and proteins but not the intact ones. In addition, the protein and carbohydrate in the extract were also associated with the browning reactions as a brown color appearance in the extracts at all the treatment temperatures. The brown substances, which included melanoidins and heterocyclic compounds that may contribute to the radical scavenging activity, would be obtained from both the Mailard browning and the caramelization reactions during the high-temperature treatment. ${ }^{[9,19]}$

Figure 2 shows the effects of the treatment temperatures on the carbohydrate and protein contents and DPPH radical scavenging activity in the extracts from the okara treated for $5 \mathrm{~min}$. Both the protein content and radical scavenging activity increased with the increasing treatment temperature. The change in the activity with treatment temperature was consistent with the protein content, but not with the carbohydrate content at the same treatment time. This fact indicates that the protein may be mainly responsible for the radical scavenging activity of the extracts. Although the change in the carbohydrate content was inconsistent with the radical scavenging activity, products from degradation of the carbohydrate, which were not positive in the phenol-sulfuric method, may contribute to the radical scavenging activity. Thus, the lower the carbohydrate content, the higher the radical scavenging activity.

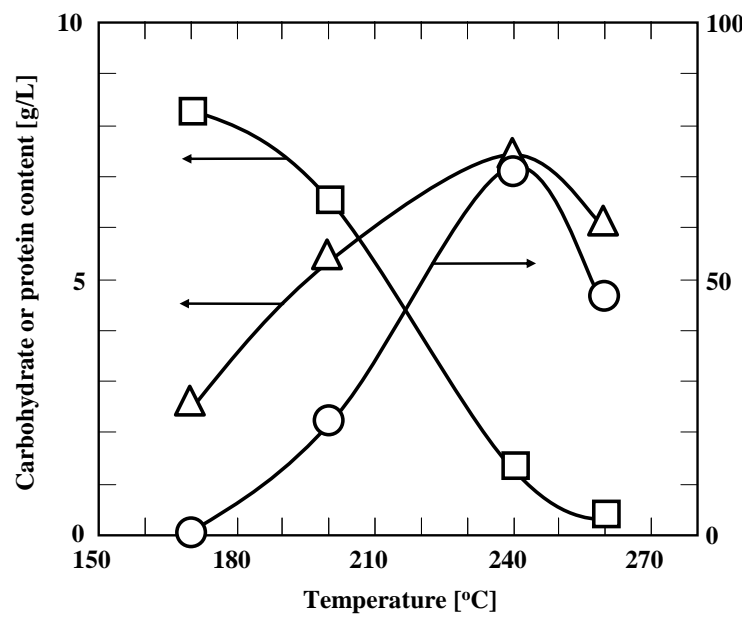

Figure 2 Dependences of the carbohydrate and protein contents, and DPPH radical scavenging activity in the extracts at different treatment temperatures for $5 \mathrm{~min}$.
The relationship between the radical scavenging activity and protein content in the extracts from the okara treated at various temperatures and times is shown in Fig. 3. At any treatment temperature and time, the increase in the protein content was positively related to the increase in the radical scavenging activity. This fact indicates that the protein contributes to the DPPH radical scavenging activity in the extracts, which agreed with several published reports. ${ }^{[4,7,20]}$.

\section{Antioxidative activity of okara extract}

According to Fig. $1 \mathrm{C}$, the okara treated at $240^{\circ} \mathrm{C}$ for 5 min provided the relatively highest radical scavenging activity and could be used for evaluation of the antioxidative activity. To compare the extract from okara with the well-known antioxidants, the ascorbic acid and the soluble soybean polysaccharide (SSPS) were chosen. Figure 4 shows the radical scavenging activity of the ascorbic acid, the soluble soybean polysaccharide, and the extract from okara at their various concentrations. The radical scavenging activity of the okara was higher than that of the SSPS, but lower than that of the ascorbic acid. Fang et al. reported that the low-molecular-weight fraction of SSPS, which contained $10 \%(\mathrm{w} / \mathrm{w})$ protein or peptide and $55 \%(\mathrm{w} / \mathrm{w})$ saccharide, had a higher radical scavenging activity than the high-molecular-weight fraction with $79.7 \%(\mathrm{w} / \mathrm{w})$ saccharide and $2.5 \%(\mathrm{w} / \mathrm{w})$ protein. ${ }^{[13]}$ This fact was consistent with the results in Figures 3 and 4 . The extract from the okara, which had a higher radical scavenging activity, would contain higher protein content than the SSPS.

To evaluate the antioxidative activity of the extract from the okara treated with the subcritical water, the

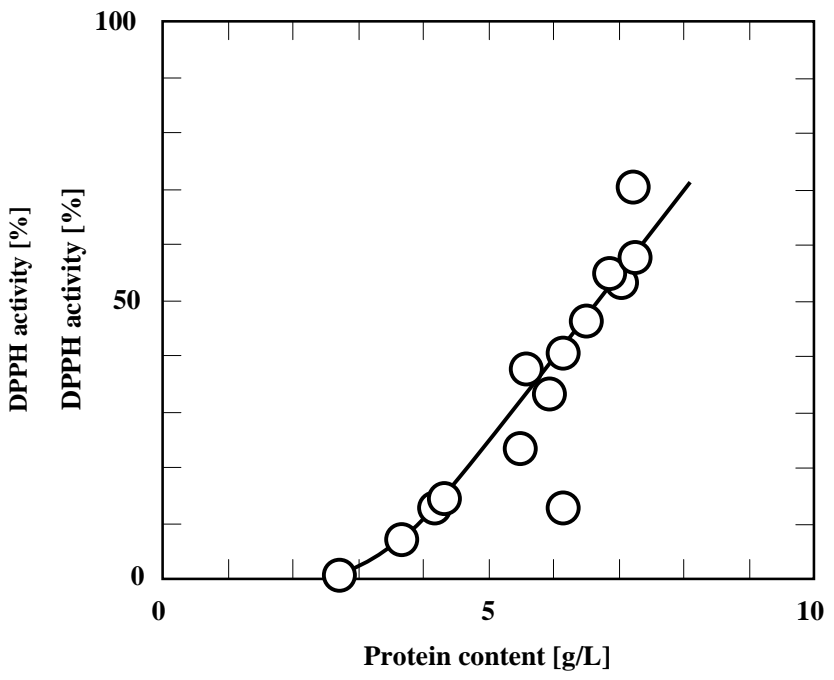

Figure 3 Relationship between protein content and DPPH radical scavenging activity in the extracts obtained at various treatment temperatures and times. 


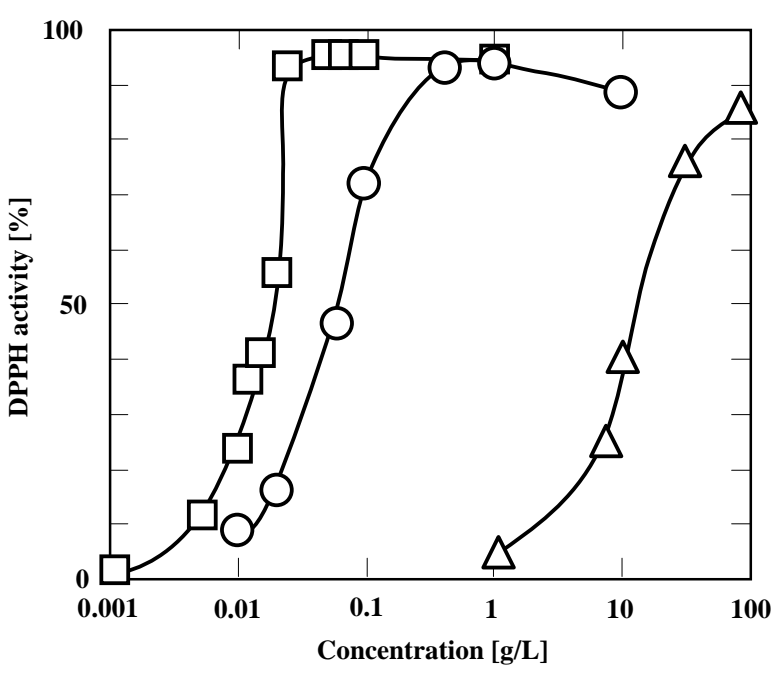

Figure 4 DPPH radical scavenging activity of the ascorbic acid $(\square)$, the extract from okara treated at $240^{\circ} \mathrm{C}$ for $5 \mathrm{~min}(\mathrm{O})$, and the soluble soybean polysaccharide $(\triangle)$ at various concentrations.

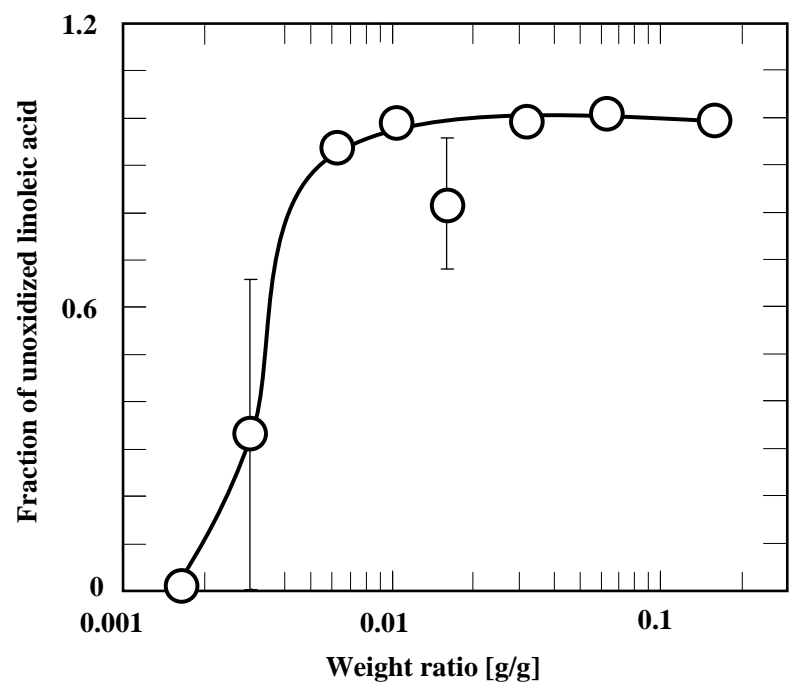

Figure 5 Suppression of linoleic-acid oxidation by the extract from okara treated at $240^{\circ} \mathrm{C}$ for $5 \mathrm{~min}$ for various weight ratios of okara extract to linoleic acid.

extract from the okara treated at $240^{\circ} \mathrm{C}$ for 5 min was also examined for the autoxidation of linoleic acid. Figure 5 shows the fraction of unoxidized linoleic acid after incubation for $12 \mathrm{~h}$, which is a measure of the oxidative stability. The fraction of unoxidized linoleic acid is plotted versus the weight ratios of the powdered extract to linoleic acid. It increased sharply between 0.0016 and 0.005 of the weight ratio, and then was nearly constant independent of the weight ratio. The higher the weight ratio, the higher the fraction of unoxidized linoleic acid and the longer the stability of the linoleic acid. The results from Figs. 4 and 5 indicate that the extract had both a DPPH radical scavenging activity and antioxidative activity against the autoxidation of linoleic acid. Both activities increased with the increasing amount of the extract.

\section{CONCLUSIONS}

The extracts from the okara treated with subcritical water contained protein and carbohydrate and had both a radical scavenging activity and antioxidative activity against the autoxidation of linoleic acid. The protein content in the extract increased with the increasing treatment temperature. However, the carbohydrate content decreased at the higher treatment temperatures from 170 to $260^{\circ} \mathrm{C}$. Both contents decreased with prolonged heating. The radical scavenging activity of the extracts increased with the increasing treatment temperature from 170 to $240^{\circ} \mathrm{C}$. The highest activity was obtained from the okara treated at $240^{\circ} \mathrm{C}$ for $5 \mathrm{~min}$, which showed an antioxidative activity against the autoxidation of linoleic acid and the activity increased with the increasing weight ratios of the extract to linoleic acid.

\section{REFERENCES}

1. O'Toole, D. K. Characteristics and use of okara, the soybean residue from soy milk production-A review. Journal of Agricultural and Food Chemistry 1999, 47, 363-371.

2. Surel, O.; Couplet, B. Influence of the dehydration process on active compounds of okara during its fractionation. Journal of the Science of Food and Agriculture 2005, 85, 1343-1349.

3. Xu, B. J.; Chang, S. K. C. Isoflavones, flavon-3-ols, phenolic acids total phenolic profiles, and antioxidant capacities of soy milk as affected by ultrahigh-temperature and traditional processing methods. Journal of Agricultural and Food Chemistry 2009, 57, 4706-4717.

4. Jiménez-Escrig, A.; Alaiz, M.; Vioque, J.; Rupérez, P. Health-promoting activity of ultra-filtered okara protein hydrolysates released by in vitro gastrointestinal digestion: identification of active peptide from soybean lipoxygenase. European Food Research and Technology 2010, 230, 655-663.

5. Yokomizo, A.; Takenaka, Y.; Takenaka, T. Antioxidative activity of peptides prepared from okara protein. Food Science and Technology Research 2002, 8, 357-359.

6. Redondo-Cuenca, A.; Villanueva-Suárez, M. J.; Mateos-Aparicio, I. Soybean seeds and its by-product okara as sources of dietary fibre. Food Chemistry 2008, 108, 1099-1105.

7. Tyug, T. S.; Prasad, K. N.; Ismail, A. Antioxidant 
capacity, phenolics and isoflavones in soybean by-products. Food Chemistry 2010, 123, 583-589.

8. Wagner, W.; Pru $\beta$, A. The IAPWS formulation 1995 for the thermodynamic properties of ordinary water substance for general and scientific use. Journal of Physical and Chemical Reference Data 2002, 31, 387-535.

9. Friedman, M. Food browning and its prevention: an overview. Journal of Agricultural and Food Chemistry 1996, 44, 631-653.

10. Manzocco, L.; Calligaris, S.; Mastrocola, D.; Nicoli, M. C.; Lerici, C. R. Review of non-enzymatic browning and antioxidant capacity in processed foods. Trends in Food Science \& Technology 2001, 11, 340-346.

11. Dubois, M.; Gilles, K. A.; Hamilton, J. K.; Rebers, P. A.; Smith, F. Colorimetric method for determination of sugars and related substances. Analytical Chemistry 1956, 28, 350-356.

12. Lowry, O. H.; Rosebrough, N. J.; Farr, A. L.; Randall, R. J. Protein measurement with the Folin-phenol reagents. Journal of Biological Chemistry 1951, 193, 265-275.

13. Fung, X.; Watanabe, Y.; Adachi, S.; Matsumura, Y.; Mori, T.; Maeda, H.; Nakamura, A.; Matsuno, R. Microencapsulation of linoleic acid with low- and high-molecular-weight components of soluble soybean polysaccharide and its oxidation process. Bioscience, Biotechnology and Biochemistry 2003, 67, 1864-1869.
14. Harado, O.; Wakita, Y.; Yoshida, K.; Ohashi, T.; Kuwata, M.; Fujimura, T. Subcritical-water treatment of okara and property of the decomposition products. Journal of the Japanese Society for Food Science and Technology 2004, 51, 149-154.

15. Ma, C.-Y.; Liu, W.-S.; Kwok, K. C.; Kwok, F. Isolation and characterization of protein from soymilk residue (okara). Food Research International 1997, 29, 799-805.

16. Sasaki, M.; Fang, Z.; Fukushima, Y.; Adschiri, T.; Arai, K. Dissolution and hydrolysis of cellulose in subcritical and supercritical water. Industrial \& Engineering Chemistry Research 2000, 39, 2883-2890.

17. Mateos-Aparicio, I.; Mateos-Peinado, C.; Jiménez-Escrig, A.; Rupérez, P. Multifunctional antioxidant activity of polysaccharide fractions from the soybean byproduct okara. Carbohydrate Polymers 2010, 82, 245-250.

18. Tyug, T. S.; Prasad, K. N.; Ismail, A. Antioxidant capacity, phenolics and isoflavones in soybean by-products. Food Chemistry 2010, 123, 583-589.

19. Benjakul, S.; Visessanguan, W.; Phongkanpai, V.; Tanaka, M. Antioxidative activity of caramelisation products and their preventive effect on lipid oxidation in fish mince. Food Chemistry 2005, 90, 231-239.

20. Takenaka, T., Tamura, Y., and Takenaka, Y. Water soluble antioxidant in supernatant fraction of okara, a by-product of tofu manufacturing. Food Science and Technology, International 1996, 2, 19-23. 